DOI: $10.17516 / 1997-1370-0356$

УДК 800:159.9

\title{
Language Consciousness of the Yakut Language Speakers
}

\author{
Marina I. Kysylbaikova* \\ M.K. Ammosov North-Eastern Federal University \\ Yakutsk, Russian Federation
}

Received 07.11.2018, received in revised form 21.11.2018, accepted 05.12.2018

\begin{abstract}
The paper proposes results of the language consciousness analysis through the concepts "Culture", "Language", "Nature", "History", "Love", "Beauty" and "Family". The aim of work is to expose the core component of the language consciousness of the Yakut language speakers. The main method of study is the associative experiment which involved questioning more than 2,000 people. Respondents of experiment were 25-65 year old people, students of different specialties, teachers, engineers, doctors, businessmen, designers, actors, accountants, etc. As a result, the analysis of associations shows that the language consciousness of the Yakut people is totally connected with the national traditional culture. Most of associations to different concepts are related to the Yakut traditions, culture, literature, beliefs, nature, science, etc. The analysis of the data obtained during the free associative experiment reveals that the structure of different concepts under study clearly shows the ethnocultural features of the representation of the Yakut language speakers. Results of research work can be used as the material for future study of Psycholinguistics, General Linguistics, Theory of Language, etc.
\end{abstract}

Keywords: concept, language consciousness, associative experiment, Yakut language

Research area: philology

Citation: Kysylbaikova, M.I. (2022). Language consciousness of the Yakut language speakers. J. Sib. Fed. Univ. Humanit. Soc. Sci., 15(3), 324-328. DOI: 10.17516/1997-1370-0356.

\footnotetext{
(C) Siberian Federal University. All rights reserved

* Corresponding author E-mail address: kysylbaikova@mail.ru ORCID: 0000-0003-2082-3883
} 


\section{Introduction}

In connection with the rapid development of the ideas of cognitive science in linguistics, conceptualization issues have recently become relevant and significant. The cognitive mechanism of a person can be understood precisely through language, therefore the study of this problem becomes inevitable.

Currently, psycholinguistic and ethno-psycholinguistic studies of language consciousness, the study of the worldview of an ethnos demonstrate a new integrated approach. The approach used in our work is aimed at identifying the ethnocultural specificity of the linguistic consciousness of representatives of various linguocultural communities.

\section{Theoretical framework}

Turning to the ethnocultural specificity of the language consciousness of a certain linguistic cognitive community, it is necessary to take into account the fact that the language of the linguocultural community members is, above all, the main tool for its assimilation and dissemination of such information for humankind.

The mental worldview, mediated by the language of a particular culture, constitutes language consciousness. In the linguistic consciousness of individuals there is a type of culture that they encounter (Gerrig, 1992: 127; Geeraerts, 1995: 87).

It is well known that each language in its own way categorises the world and determines a way of conceptualizing reality that is unique only for a given linguistic culture. On the other hand, the culture in which the given language was once formed and functions now imposes an indelible imprint on the peculiarities of the linguistic perception of reality and the linguistic consciousness of the speakers of a given language.

\section{Statement of the problem}

Studying a language from different perspectives, namely from the point of view of a cognitive approach, helps to look into the person him-/herself with all the correspondent intellectual, mental, social, ethno-national and other components. In this regard, a person be- comes the center of attention of many studies, while the language of a person becomes the focus of research of linguists (Filippova, 2014: 203). The aim of the present work is to reveal the core of the language consciousness of the Yakut language speakers through the analysis of different concepts.

\section{Methods}

In this work a free associative experiment was chosen as a research method as this experiment allows us to find out how fragments of language consciousness are arranged in native speakers' minds. We agree with the opinion of V.P. Belianin who believes that "the associative experiment shows the presence in the meaning of a word (as well as a subject denoted by a word) of a psychological component. Thus, an associative experiment makes it possible to construct the semantic structure of a word. It serves as a valuable material for studying the psychological equivalents of what in linguistics is called the semantic field, and brings out into the open the semantic connections of words that objectively exist in the psyche of a native speaker. In this connection it should be noted that the main advantage of an associative experiment is its simplicity, ease of use, as it can be conducted for a large group of people at the same time" (Belianin, 2007: 129).

The questionnaire is the main tool in the associative experiment which makes the linguistic ability of native speakers available for our observation. Yu.N. Karaulov mentions that "syntactic structures fixed in stimulus-response pairs are reproduced spontaneously and unconsciously like any other integral unit as they were used repeatedly in the texts of a given linguistic person or their reference group" (Karaulov, 1999: 68).

Hence, associative fields present more accurate data content, they contain not only internally developed knowledge, but also sensory data characteristic of each person and each national consciousness. The proximity of associative fields in different languages or their difference (besides linguistic reasons) can be explained by the coincidence or inconsistency of the main forms of culture. 


\section{Discussion}

2,000 Yakut language speakers took part in our associative experiment, all of them were 25-65 years old. Social strata of the respondents: representatives of diplomatic missions, teachers, businessmen, missionaries, volunteers, tourists, respondents of various specialties, respondents of various social categories, students, etc.

Associative experiment with different concepts ("Culture", "Language", "Nature", "History", "Love", "Beauty", "Family") was made in the period 2012-2017. Respondents were given a questionnaire list consisting of 50 words, 30 stimulus-words among them.

For instance, the following reactions were presented by the Yakut language speakers for the stimulus-word "Tradition" (concept "Culture").

The table shows that the most frequent response of the Yakut language speakers is suguruyuu / worship. In the understanding of the Yakut people suguruyuu / worship is one of the main traditions of the Sakha people. Native speakers of the Yakut language more bow Aiyy to the Deities, the worship ceremony to the Deities can be seen in all large-scale

Table

\begin{tabular}{|c|c|}
\hline Reactions & Quantity \\
\hline suguruyuu / worship & $30 \%$ \\
\hline yhyah / ysyakh & $25 \%$ \\
\hline olonkho / olonkho & $10 \%$ \\
\hline bult / hunt & $4 \%$ \\
\hline byraabyla / rules & $4 \%$ \\
\hline Ite5el / faith, religion & $4 \%$ \\
\hline nomoh / saying & $4 \%$ \\
\hline sier-tuom / ritual & $4 \%$ \\
\hline tuom, duom / rite & $4 \%$ \\
\hline kharystaahyn / compliance & $4 \%$ \\
\hline aiyl5a / nature & $2 \%$ \\
\hline aiyy / sacred & $2 \%$ \\
\hline kuha5an / poor & $2 \%$ \\
\hline siri-uotu ahatyy / treating the & $2 \%$ \\
\hline spirits of the earth, fire & $2 \%$ \\
\hline uchugey / good & \\
\hline
\end{tabular}

events, as it is intrinsic in the tradition of the Yakut culture. Yhyah (Ysyakh) is a national holiday of the Yakuts, a meeting of the summer, a holiday of the awakening of nature and abundance. Various ritual actions and rituals are performed on this holiday. Nowadays in the frenzied rhythm of modern life when the old foundations are supplanted no one is particularly trying to maintain rituals. And only once a year, on Yhyah, one can observe the careful and accurate practice of the rituals of our ancestors. It is on this national holiday that one can see sundry rituals of worshipping the highest Deities.

It should be noted that the blessing (algys) as a ritual is usually made together with the rite of treating the spirits of fire or earth. Algys is an appeal to a higher power, the spirits of earth and sky with a request or gratitude. Traditions

Single answers:

\begin{tabular}{|c|c|}
\hline Reactions & Quantity \\
\hline djol / happiness & $0,3 \%$ \\
\hline mas / wood & $0,3 \%$ \\
\hline us kut / soul of man & $0,3 \%$ \\
\hline uhuyeen / myth & $0,3 \%$ \\
\hline $\begin{array}{c}\text { Aiyylarga suguruyuu / wor- } \\
\text { ship of the highest gods }\end{array}$ & $0,25 \%$ \\
\hline cepseen / story & $0,25 \%$ \\
\hline custom / custom & $0,25 \%$ \\
\hline algys / blessing & $0,2 \%$ \\
\hline Bayanay / spirit of the forest & $0,2 \%$ \\
\hline literature / literature & $0,2 \%$ \\
\hline novella / short story & $0,2 \%$ \\
\hline ostuoruya / fairy tale & $0,2 \%$ \\
\hline traditsiya / tradition & $0,2 \%$ \\
\hline uut / milk & $0,2 \%$ \\
\hline elbehter / many & $0,2 \%$ \\
\hline cultura / culture & $0,15 \%$ \\
\hline noruot / people & $0,15 \%$ \\
\hline oyuunnaahyn / shamanism & $0,15 \%$ \\
\hline zanudno / boring & $0,1 \%$ \\
\hline tyl / tongue & $0,1 \%$ \\
\hline uye / century & $0,1 \%$ \\
\hline ebuge ugehe / custom ancestors & $0,1 \%$ \\
\hline
\end{tabular}


are also kept in significant events: when a child is born; when housewarming is celebrated; at weddings and funerals. Hunters also adhere to their rites, there is a number of unwritten rules that must be followed in nature when hunting. Ritual is always associated with beliefs, religion. The Yakuts believe in spirits, deities, and this is reflected in their answers: the sacred Urung Aar Toion - the supreme god and Bayanay - the spirit of the forest, the patron saint of hunters.

According to the data obtained the core of the concept "Culture" in the language consciousness of the Yakut language speakers is "folklore".

The first layer of the structure of the concept "Culture" in the Yakut language is represented by the signs "Art", "Science", "Literature".

The second layer: "Language", "Sport", "Education".

The third layer: "Faith", "Soul", "Geography", "Family".

The collected data make it possible to conclude that for the Yakut people "culture" is folklore. The available data of the Yakut language speakers confirm that the culture of the Yakuts is based on folklore which is oral folk art. The folklore of the Sakha people is known for its rich diversity.

It should also be stated that it is impossible to imagine the culture of the Yakuts without folklore. The genre composition is inexhaustible and manifold: olonkho, fairy tales, songs, stories, historical legends, riddles, tongue twisters, proverbs and sayings, etc. Folklore has its specific features: traditionalism, orality, collectivity and variability. Oral-poetic creativity emerged simultaneously with the ethnic formation of the Sakha people.

One more example is reactions to the stimulus-word "Literature". Native speakers of the Yakut language cited a large number of references to Yakut writers and the names of famous works as associations for the stimulus-word "Literature". It is gratifying that the Yakuts honor their native classical literature, do not forget about the first works of Yakut literature and also the first founders of it. Along with the Yakut authors, the classics and con- temporaries of foreign literature, the names of famous works of foreign authors, the names of periodicals were mentioned, too.

As for the concept "Nature", the reactions turned out to be very miscellaneous and complex. It is worth noting that reactions are often associated with the spiritual world, with nature, with the exceptional culture of the Sakha people. Native speakers of the Yakut language presented relatively many synonymous associations related to patriotism, their homeland, frequently referred to the birthplace, and, in contrast, to the place of their temporary residence.

\section{Conclusion}

Summing up, I come to the conclusion that culture is a universal concept. Culture is displayed in language, the very language is culture. Language is one of the most specific components of any ethnic culture. Ethnicity makes this or that culture special. The study of national linguistic, ethnic consciousness allows us to formulate the worldview of the bearers of a particular linguoculture. It is the language consciousness that is especially important when interpreting the thoughts and conveying the way of thinking.

The Yakuts, having appeared as a nation (as a Turkic ethnic community) before the arrival of the Russians, are experiencing a further evolution in their ethnic development. In the process of interethnic contacts the Sakha people have acquired an ethnic identity, a national identity and a national ideology. It should also be noted that in the process of interethnic contacts there arise a cultural diversity of an ethnos and its specific national forms. It is known that already in the pre-revolutionary period the emerging Yakut ethnic intelligentsia used ethnicity as a consolidating factor in the development of the Sakha people.

As for the language consciousness of the Yakut respondents the data obtained prove that in order to have complete knowledge of the presentation and content about their culture, the carrier of the cultural code must know about the traditional components of the native culture, respect the customs, and be able to accept the characteristics of other cultures. 
In the conditions of a sharp increase of the role of national, ethnic factors, the scientific understanding of this phenomenon becomes extremely important as an integral element of the interethnic communication system in which ethnic and ethnocultural processes take place.

\title{
References
}

Belianin, V.P. (2007). Psikholingvistika [Psycholinguistics]. Moscow, Flinta, 232 p.

Filippova, S.V. (2014). The "Man" associative fields in the Yakut and Russian linguistic consciousnesses. In Journal of language and literature, 5 (3), 203-209. DOI: 10.7813/j11.2014

Geeraerts, D. (1995). Cognitive Linguistics. Amsterdam, John Benjamins, 116 p.

Gerrig, R. (1992). Contextual influences on the comprehension of complex concepts. Language and cognitive processes. Tokyo, Utrecht, $397 \mathrm{p}$.

Karaulov, Yu.N. (1999). Aktivnaia grammatika i assotsiativno-verbalnaia set' [Active grammar and associative-verbal network]. Moscow, Institut russkogo iazyka RAN [RAS, Institute of Russian Language], $180 \mathrm{p}$.

\section{Языковое сознание носителей якутского языка}

\section{М.И. Кысылбаикова}

Северо-Восточный федеральный университет

им. М.К. Аммосова

Российская Федерачия, Якутск

\begin{abstract}
Аннотация. В статье представлены результаты анализа языкового сознания через концепты «культура», «язык», «природа», «история», «любовь», «красота», «семья». Цель работы - выявление основного компонента языкового сознания носителей якутского языка. Основным методом исследования служит ассоциативный эксперимент (анкетирование), который проводился среди более чем 2000 человек. Респондентами эксперимента являются люди в возрасте 25-65 лет различных специальностей, например учителя, инженеры, врачи, бизнесмены, дизайнеры, актеры, бухгалтеры и т. д., а также студенты. В результате анализ ассоциаций показывает, что языковое сознание якутов полностью связано с национальной традиционной культурой. Большинство ассоциаций на различные концепты связаны с якутскими традициями, культурой, литературой, верованиями, природой, наукой и т.д. Анализ данных, полученных по результатам свободного ассоциативного эксперимента, показывает, что структура изучаемых понятий ясно отображает этнокультурные особенности представления якутов. Результаты исследовательской работы могут быть использованы в качестве материала для будущего изучения психолингвистики, общего языкознания, теории языка и т. д.
\end{abstract}

Ключевые слова: концепт, языковое сознание, ассоциативный эксперимент, якутский язык.

Научная специальность: 10.00 .00 - филологические науки. 